\title{
Sustainable urban development and industrial pollution
}

\author{
Article history: \\ Received: 1 December 2015 \\ Sent for revision:27 December 2015 \\ Received in revised form:11 February 2016 \\ Accepted: 12 February 2016 \\ Available online: 1 April 2016
}

\begin{abstract}
Sustainable development of cities is highly connected with the pollution generated from industrial facilities and power plants. Both affect quality of air, weather, health and quality of life. The main goal of this paper is to determine the impact of selected weather parameters on the pollution from mentioned plants. From the research results, it can be concluded that sustainable urban development and welfare of citizens are dependent on causal relationship between pollution and weather. The greatest level of impact was recorded for nitric dioxide. In the case of carbon monoxide, the level of impact is the middle. The lowest level was recorded for particulate matter. The biggest impact on the carbon monoxide emission and particulate matter is that of air pressure, whereas temperature has the biggest impact on nitrogen dioxide emission. The research shows that air humidity and wind speed do not have a significant impact on the emission of pollutants from the plants. Research shows need for further studies in the field of impact of pollution from industry on urban weather and human health.
\end{abstract}

Key words: urban development, industrial pollution, weather parameters

\section{Održivi urbani razvoj i industrijsko zagađenje}

Apstrakt: Održivi razvoj gradova je visoko povezan sa zagađenjem koje nastaje kao posledica rada industrijskih postrojenja i termalnih toplana. Obe vrste postrojenja utiču na kvalitet vazduha, vreme, zdravlje i kvalitet života. Osnovni cilj ovog rada je da utvrdi uticaj odabranih vremenskih parametara

\footnotetext{
${ }^{1}$ Novi Sad Heating Plant Public Utility, Serbia, julka.petrovic@nstoplana.rs

${ }^{2}$ University of Novi Sad, Faculty of Technical Sciences, Serbia

${ }^{3}$ NIS Gazprom Neft, Novi Sad, Serbia
} 
na zagađenje koje nastaje radom navedenih postrojenja. Na osnovu istraživačkih rezultata može se zaključiti da je održivi urbani razvoj i dobrobit građana zavistan od uzajamnog odnosa između zagađenja $i$ vremenskih prilika. Najveći stepen uticaja je zabeležen u slučaju ugljen monoksida. U slučaju azot dioksida, nivo uticaja je umeren. Najniži uticaj je zabeležen u slučaju praškastih materija. Najveći uticaj emisija ugljen monoksida $i$ praškastih materija se vrši na vazdušni pritisak, dok temperature i brzina vetra nemaju značajan uticaj na emisiju polutanata iz ispitivanih postrojenja. Istraživanje je pokazalo da su potrebne dalje studije na polju uticaja industrijskog zagađenja na urbane klimatske prilike i ljudsko zdravlje.

Ključne reči: urbani razvoj; industrijsko zagađenje; vremenski parametri

\section{Introduction}

Sustainable development, including urban development, is under constant monitoring in the EU (Bujanowicz-Haraś et al, 2015; Sucic et al, 2014), especially in energy-related issues (Żelazna and Gołębiowska, 2015; Duran et al, 2013). Urban development is connected with significant number of specific problems related to the environment, quality of life, construction, transport and other aspects of life. Modern sustainable cities must respect "culture, science, technology and innovation, and policies in urban, economic and social development" (Yigitcanlar, O'Connor and Westerman, 2008), with master planning approach to the development (Halla, 2007). Special attention in this sense must be given to the relation between urban agglomeration and environment (Xian, Crane and Su, 2007), waste (Corvellec, Campos and Zapata, 2014), as well as with climate change (Ewing et al, 2007).

Air pollution, because of industry and thermal power plants, is a subject of numerous studies and due to its significance and potential detrimental impact on health of a great number of people; it is under strict control (Staffogia et al, 2008; Tsai, Lin and Lee, 2003). Researches impede the fact that it is difficult to identify the source of air pollution, especially in large cities (Kindap, 2008; Ricardo et al, 2004; Mazzeo and Venegas, 2004). On the other hand, the impact of weather conditions on pollution from district heating thermal power plants is addressed in a smaller number of studies (Laurikka and Koljonen, 2006; He, Ye and Zhao, 2013), while the results are often inconclusive and contradictory (Tang, Rayner and Haeger-Eugensson, 2011; Galindo, 2011; Piro et al, 2009).

With the occurrence of a more significant climate change, unforeseen and sudden changes in climate conditions in a smaller area, research activities dealing with the impact of weather conditions on pollution from industry and thermal power plants, both on certain pollutants and on the pollution in its 
entirety, have been launched (Zanobetti and Peters, 2015; Green et al, 2004). Research involves all main pollutants that may have a detrimental impact on people and the environment (Magiera, Goluchowska and Jabłońska, 2013; Rocher et al, 2004). Namely, numerous research works show that, although within the limits of legally permissible, long-term (multi-decade) pollution taking place on a specific territory can have a detrimental effect on human health (Djordjevic et al, 2011; Valkonen et al, 1995). Coupled with a visible climate change, the intensity of the impact can be even greater (Yucheng and Ce, 2015; Carreras, Chellini and Blangiardo, 2012). In accordance with globally adopted efforts aimed at reduction of $\mathrm{CO}_{2}$ emission, studies on both regional and national level, as well as on the level of individual cities, are of exceptional importance. Specific climatic conditions characteristic of certain area are addressed (Zuo and Chen, 2015; Brookes and Locatelli, 2015), whereby site aspects are to be, by all means, also taken into account (Kuznetsova et al, 2008; Castelli, Anfossi and Ferrero, 2003). In spite of the fact that from an environmental aspect, existence of a greater number of smaller thermal energy plants is more acceptable than a smaller number of bigger ones (Al-Gharib, Elkamel and Baker, 2002; Nikolić, 2015), conducting identical microclimate observation is recommended for each plant (Alanne and Saari, 2006; Cheng et al, 2007).

In addition to that, certain combination of a few weather parameters can create perfect conditions for non-dispersion and concentration of greater quantities of pollutants on a specific territory, which is not possible to be eliminated by any activity of man (Bezglaya, Ivleva and Smirnova, 2013). The research is greatly gaining in importance due to the creation of everincreasing human agglomerations, with millions of people living in a small area and using a district heating system (Sirotenko et al, 2008; Wissner, 2014). Cities (and in particular megalopolises), have their own microclimate which can in different ways affect distribution of pollutants (Cho and Choi, 2014; Arvin, Pardhan and Norman, 2015; Leuzzi, Monti and Amicarelli, 2010). The situation is additionally gaining in complexity due to the fact that district heating thermal energy plants are already located, and will be in the future in cities (Finney et al, 2012; Kaasik, Kimmel and Kaasik, 2001). The possibility of breakdowns and industrial disasters in thermal heating plants imposes an additional need to get to know the impact of weather conditions on particulate matters (Poykio, Nurmesniemi, and Keiski, 2008). Prevailing weather conditions, or those forecast at the time of increased pollution, can significantly determine the type of impact and consequences of pollution on the shorter and longer run (Katsoulis and Pneymatikos, 2009; Astel et al, 2010).

A particularly extensive research on pollution from operation of district heating thermal power plants, as well as the impact of weather conditions on pollutants, is conducted in China as a country facing a great problem of 
pollution (Streets and Waldhoff, 2000; Zhang, Chen and Murlis, 2009). Results show that all regions of China, including Hong Kong and Taiwan, encounter the issue of increased pollution and thermal power plant emissions account for a great portion of that. Primary research conducted in China shows that identical problems relating to the impact of air pollution from district heating, as well as the impact of atmospheric factors on particulate matters occur in certain urban environments (Urumqi District Heating Project, 2011).

Research of the impact of weather conditions on pollution from heating plants is also conducted in the Russia. General conclusion is that, out of all weather parameters, temperature has the greatest impact on the intensity of air pollution with $\mathrm{CO}_{2}$ (Ryaboshapko and Revokatova, 2015), whereby the values of the other parameters change depending on the on the season (Shahgedanova, Burt, and Davies, 1999).

In the countries of the Western Balkans, there is generally present a high level of uncontrolled environmental pollution, which is, like in majority of developing countries, predominantly a consequence of the use of obsolete technology (Stefanović et al, 2008; Poupkou, 2007) outdated utility regulation (Gassner and Pushak, 2014; Alexander, 2014), whereby the energy prices (especially electricity) largely involves social component (Filipović, Nikolić and Dragutinović, 2012). In Serbia, environmental issues relating to the operation of thermal energy plants are in particular grave, as great quantities of hazardous gases are produced during oil combustion (Jovanović and Komatina, 2012). On the other hand, district heating plants in majority cases burn natural gas, and the pollution they generate is within tolerance levels. Besides that, introduction and application of state-of-the-art methods of pollution control in thermal power plants has significantly facilitated and speeded up the control system and has had a positive impact on the quality of living environment as a whole (Mikulandrić et al, 2012). The research undertaken in the field of application of cogeneration plants will also result in an improved situation in this field, as cogeneration plants have numerous economic and environmental advantages (Stojiljković et al, 2010), but there are numerous barriers for faster economic and technological development (Filipović and Miljković, 2014; Filipović and Miljković, 2011).

It is known that so far, only one practical study dealing with the assessment of the impact of weather parameters on the degree of pollution from a thermal energy plant was conducted on the territory of the Western Balkans and the conclusion drawn is that the greatest individual impact is that of the temperature gradient. Due to the above stated issues, obsolete technology and insufficient financial resources, countries of the Western Balkans are currently working out their own plans for the future development of energy sector, with different scenarios yielding different results and requiring different 
Petrović J. et al.: Sustainable urban development and industrial pollution

levels of investments and institutional support (Tomasović et al, 2014; Borović, 2014).

\section{Methodology of the research}

\subsection{Research plant}

The research was conducted on four thermal energy plants in city of Novi Sad, Serbia (Novi Sad Heating Plant Public Utility). Data were obtained for four thermal energy plants with 12 boilers in total (Report on the measurement of emissions of pollutants in the air, 2011, 2012 and 2013). District heating system and locations of facilities are shown at Figure 1.

Figure 1. Novi Sad Heating Plant Public Utility, Serbia District heating system and locations of facilities

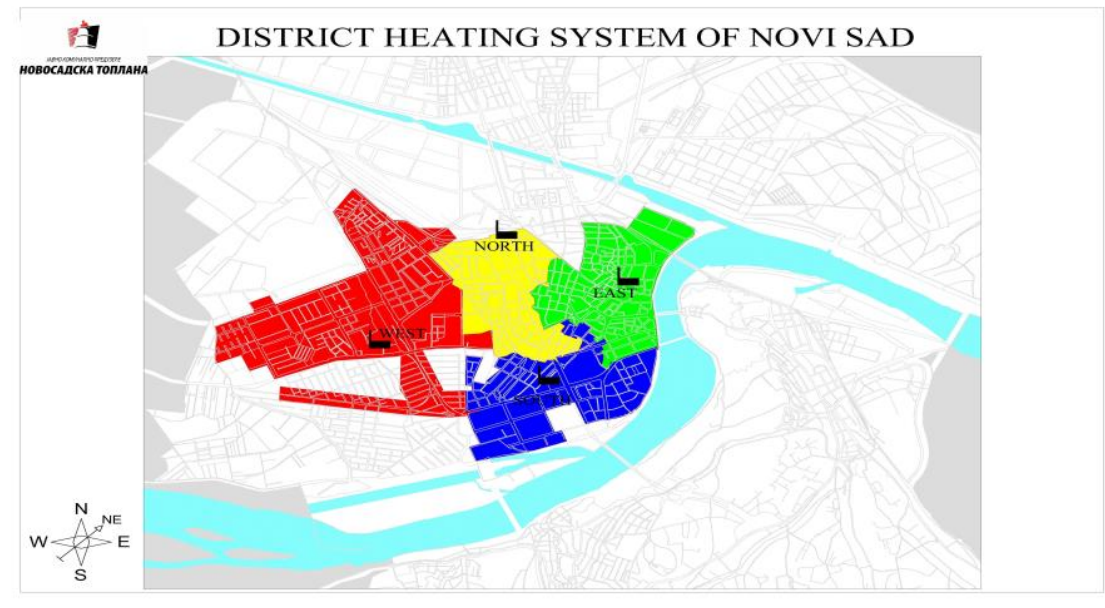

Regular measurements of emissions are carried out at four plants:

TO NORTH - Thermal power plant NORTH

TO EAST - Thermal power plant EAST

TO WEST - Thermal power plant WEST

TO SOUTH - Thermal power plant SOUTH

Predominant direction of the wind is northeast.

\subsection{Data processing technique}


Data were processed by applying the panel data analysis method, as the subject method, due to its characteristics, can be deemed suitable for the research of this kind. panel data analysis is a statistical method, used in social science, epidemiology, and econometrics (Heckman and Learner, 2007). Data are collected over certain period and on the same individuals and then a regression is run over these two dimensions. The panel data regression model is $y_{i t}=a+b x_{i t}+\varepsilon_{i t}$, whereby $y$ is the dependent variable, $x$ is the independent variable, "a" and "b" are coefficients, " $\mathrm{i}$ " and " $\mathrm{t}$ " are indices for individuals and time (Matyas and Sevestre, 2008). The error $\varepsilon_{\text {it }}$ is a very important parameter in the panel data analyis (Baltagi, 2013). Assumptions about the error term determine whether the effects are fixed or random. In a fixed effects model, $\varepsilon_{\mathrm{it}}$ is assumed to vary non-stochastically over "i" or " $\mathrm{t}$ ". The fixed effects model is analogous to a dummy variable model in one dimension. In a random effect model, $\varepsilon_{i t}$ is assumed to vary over stochastic "i" or "t" requiring special treatment of the error variance matrix (Davies and Lahiri, 1995). Panel data analysis has several advantages over crosssectional or time-series data. First, it provides a more accurate inference of model parameters - panel data usually contain more degrees of freedom and greater sample variability. Second, it has a greater capacity of capturing the complexity of human behaviour than a single cross-section or time series data - that includes: constructing and testing more complex behavioural hypotheses, controlling the impact of omitted variables, uncovering dynamic relationships, generating more accurate predictions for individual outcomes by pooling, providing micro foundations for aggregate data analysis. Finally, the panel data analysis enables a simplified computation (Wooldridge, 2002).

Panel data analysis can be used in three independent approaches: 1) independently pooled panels, 2) random effect models and 3) fixed effect models or first differentiated models (Chen, 2013). The selection between these methods depends on the objective of our analysis. Having considered the advantages of the applied panel data analysis to other similar methods, while taking into account aims of the research, the fixed effect model method $R$ software version 2.8.0 was selected as a method to be used in the research.

There are two groups of data used in the research. The first group of data is related to pollution. The second group of data are data on weather parameters.

\subsection{Dependent variables - emission data}

Emission data for twelve boilers in three years were observed in the paper.

Table 1. Basic data on measurement of emission on boilers of Novi Sad Heating Plant Public Utility, Serbia 
Petrović J. et al.: Sustainable urban development and industrial pollution

\begin{tabular}{|c|c|c|c|c|}
\hline Boiler & Year & $\begin{array}{c}\text { Carbon monoxide } \\
\mathrm{CO}(\mathrm{mg} / \mathrm{Nm} 3)\end{array}$ & $\begin{array}{c}\text { Nitrogen dioxide } \\
\text { NO2 }(\mathrm{mg} / \mathrm{Nm} 3)\end{array}$ & $\begin{array}{l}\text { Particulate matter } \\
\text { PM (mg/Nm3) }\end{array}$ \\
\hline EAST-3 & 2011 & 0.00 & 98.00 & 0.46 \\
\hline EAST -3 & 2012 & 45.22 & 130.90 & 3.04 \\
\hline EAST -3 & 2013 & 17.04 & 145.57 & 0.34 \\
\hline WEST-1 & 2011 & 0.00 & 102.00 & - \\
\hline WEST -1 & 2012 & 46.69 & 157.78 & - \\
\hline WEST - 1 & 2013 & $\frac{40.00}{17.60}$ & 173.50 & - \\
\hline WEST -2 & 2011 & 0.00 & 127.00 & - \\
\hline WEST -2 & 2012 & 39.93 & 103.70 & - \\
\hline WEST -2 & 2013 & 1.22 & 136.06 & - \\
\hline WEST -3 & 2011 & 0.00 & 217.00 & - \\
\hline WEST -3 & 2012 & 4.96 & 220.66 & - \\
\hline WEST -3 & 2013 & 1.36 & 233.11 & - \\
\hline WEST -5 & 2011 & 0.00 & 226.00 & 0.94 \\
\hline WEST -5 & 2012 & 73.20 & 194.40 & 0.35 \\
\hline WEST -5 & 2013 & 3.82 & 221.41 & 0.70 \\
\hline WEST -6D & 2011 & $\frac{0.02}{79.00}$ & 134.00 & 0.45 \\
\hline WEST -6D & 2012 & 71.92 & 156.24 & 0.42 \\
\hline WEST -6D & 2013 & 40.92 & 157.44 & 0.23 \\
\hline WEST -6L & 2011 & 0.00 & 152.00 & 0.29 \\
\hline WEST -6L & 2012 & 75.95 & 187.55 & 0.18 \\
\hline WEST -6L & 2013 & 54.24 & 94.56 & 0.20 \\
\hline NORTH-1 & 2011 & 0.00 & 136.00 & 3.74 \\
\hline NORTH -1 & 2012 & 61.20 & 169.20 & 4.03 \\
\hline NORTH -1 & 2013 & 0.00 & 185.13 & 3.50 \\
\hline SOUTH-1 & 2011 & 0.00 & 127.00 & 0.42 \\
\hline SOUTH -1 & 2012 & 68.25 & 181.65 & 1.79 \\
\hline SOUTH -1 & 2013 & 10.78 & 96.59 & 0.24 \\
\hline SOUTH -3 & 2011 & 0.00 & 98.00 & - \\
\hline SOUTH -3 & 2012 & 45.22 & 130.90 & - \\
\hline SOUTH -3 & 2013 & 17.04 & 145.57 & - \\
\hline SOUTH -5 & 2011 & 0.00 & 102.00 & 0.61 \\
\hline SOUTH -5 & 2012 & 46.69 & 157.78 & 2.67 \\
\hline SOUTH -5 & 2013 & 17.60 & 173.50 & 1.31 \\
\hline SOUTH -8 & 2011 & 0.00 & 127.00 & - \\
\hline SOUTH -8 & 2012 & 39.93 & 103.70 & - \\
\hline SOUTH -8 & 2013 & 1.22 & 136.06 & - \\
\hline
\end{tabular}

Source: Report on the measurement of emissions of pollutants in the air (2011-2013)

In Table 1, data on emission of carbon monoxide, nitrogen dioxide and particulate matter are presented. Data on sulphur dioxide are not included in the research as reports on measurements do not contain data on measured values of sulphur dioxide or the measured values equal zero.

\subsection{Independent variables - weather parameters data}

For the purpose of the research, four primary indicators of weather conditions are used: air temperature, air humidity, air pressure and wind speed (Meteorological yearbook 1, 2 and 3). In order to obtain a clearer picture of the weather conditions, direction of the wind at the time of measurement has been indicated. The values of the measured weather indicators are given in Table 2. 
Petrović J. et al.: Sustainable urban development and industrial pollution

Table 2. Values of weather indicators recorded on boilers of Novi Sad Heating Plant Public Utility, Serbia

\begin{tabular}{|c|c|c|c|c|c|c|}
\hline Boiler & Year & $\begin{array}{c}\text { Temperature } \\
\left({ }^{\circ} \mathrm{C}\right)\end{array}$ & $\begin{array}{c}\text { Air } \\
\text { humidity } \\
(\%)\end{array}$ & $\begin{array}{l}\text { Air pressure } \\
\qquad(\mathrm{mb})\end{array}$ & $\begin{array}{l}\text { Wind } \\
\text { speed } \\
(\mathrm{m} / \mathrm{s})\end{array}$ & $\begin{array}{c}\text { Wind } \\
\text { direction }\end{array}$ \\
\hline EAST-3 & 2011 & 11.30 & 81 & 1011.70 & 2.40 & ENE \\
\hline EAST-3 & 2012 & 11.00 & 76 & 1004.70 & 2.60 & $\mathrm{~N}$ \\
\hline EAST-3 & 2013 & -3.00 & 99 & 1015.60 & 4.40 & SSE \\
\hline WEST-1 & 2011 & -1.20 & 97 & 1021.20 & 0.80 & $\mathrm{NE}$ \\
\hline WEST -2 & 2011 & -1.20 & 97 & 1021.20 & 0.80 & $\mathrm{NE}$ \\
\hline WEST -3 & 2011 & -1.20 & 97 & 1021.20 & 0.80 & $\mathrm{NE}$ \\
\hline WEST -5 & 2011 & -1.20 & 97 & 1021.20 & 0.80 & $\mathrm{NE}$ \\
\hline WEST -6D & 2011 & -1.20 & 97 & 1021.20 & 0.80 & $\mathrm{NE}$ \\
\hline WEST -6L & 2011 & -1.20 & 97 & 1021.20 & 0.80 & $\mathrm{NE}$ \\
\hline WEST - 1 & 2012 & 10.00 & 71 & 1010.30 & 2.60 & SW \\
\hline WEST -2 & 2012 & 10.00 & 71 & 1010.30 & 2.60 & SW \\
\hline WEST -3 & 2012 & 10.00 & 71 & 1010.30 & 2.60 & SW \\
\hline ZAPAD-5 & 2012 & 11.00 & 71 & 1007.20 & 2.10 & SW \\
\hline WEST -6D & 2012 & 3.00 & 81 & 994.40 & 8.70 & NW \\
\hline WEST -6L & 2012 & 3.00 & 81 & 994.40 & 8.70 & NW \\
\hline WEST -1 & 2013 & 3.60 & 79 & 1015.60 & 0.80 & SW \\
\hline WEST -2 & 2013 & 3.60 & 79 & 1015.60 & 0.80 & SW \\
\hline WEST -3 & 2013 & 3.60 & 79 & 1015.60 & 0.80 & SW \\
\hline WEST -5 & 2013 & 3.00 & 81 & 1024.30 & 2.40 & WSW \\
\hline WEST -6D & 2013 & 4.20 & 82 & 1019.90 & 2.40 & WSW \\
\hline WEST -6L & 2013 & 4.20 & 82 & 1019.90 & 2.40 & WSW \\
\hline NORTH-1 & 2011 & -0.90 & 99 & 1019.50 & 2.40 & ESE \\
\hline NORTH-1 & 2012 & 10.00 & 71 & 1002.60 & 6.20 & NW \\
\hline NORTH-1 & 2013 & -1.40 & 99 & 1021.10 & 2.40 & NW \\
\hline SOUTH-1 & 2011 & -0.90 & 99 & 1019.50 & 2.40 & ESE \\
\hline SOUTH -3 & 2011 & -1.80 & 98 & 1020.70 & 0.80 & $\mathrm{NE}$ \\
\hline SOUTH -5 & 2011 & -1.10 & 99 & 1020.70 & 0.80 & $\mathrm{NE}$ \\
\hline SOUTH -8 & 2011 & -0.90 & 99 & 1019.50 & 2.40 & ESE \\
\hline SOUTH -1 & 2012 & 12.00 & 67 & 996.60 & 5.10 & NW \\
\hline SOUTH -3 & 2012 & 9.00 & 71 & 1008.00 & 5.10 & NW \\
\hline SOUTH -5 & 2012 & 9.00 & 71 & 1008.00 & 5.10 & NW \\
\hline SOUTH -8 & 2012 & 12.00 & 62 & 1002.20 & 5.10 & NW \\
\hline SOUTH -1 & 2013 & -1.00 & 90 & 1015.20 & 4.40 & ESE \\
\hline SOUTH -3 & 2013 & -1.00 & 90 & 1015.20 & 4.40 & ESE \\
\hline SOUTH -5 & 2013 & -6.30 & 89 & 1029.90 & 0.80 & SW \\
\hline SOUTH -8 & 2013 & -1.00 & 90 & 1015.20 & 4.40 & ESE \\
\hline SOUTH -3 & 2011 & -1.80 & 98 & 1020.70 & 0.80 & $\mathrm{NE}$ \\
\hline SOUTH -5 & 2011 & -1.10 & 99 & 1020.70 & 0.80 & $\mathrm{NE}$ \\
\hline SOUTH-8 & 2013 & -1.00 & 90 & 1015.20 & 4.40 & ESE \\
\hline
\end{tabular}

Source: Meteorological yearbook (2011-2013)

Where:

ENE - East-northeast wind

$\mathrm{N}$ - North wind

SSE - South-southeast wind

$\mathrm{NE}$ - Northeast wind

SW - Southwest wind

NW - Northwest wind

WSW - West-southwest wind 
Petrović J. et al.: Sustainable urban development and industrial pollution

ESE - East-southeast wind

\section{Results and discussion}

The research was conducted in two stages.

\subsection{First research stage}

In accordance with the application methodology of panel data analysis, in the first research stage data were entered in $\mathrm{R}$ software. After data entry, a dummy variable was determined and applied - a binary variable that is coded to either one or zero. It is commonly used to examine group and time effects in regression analysis. 2011 TO EAST data were used as a dummy variable in this model.

\subsection{Second research stage}

In the second research stage, values for TO EAST, as a dummy variable, were compared to the data obtained on other measurement sites. In that phase of the research a degree of impact of weather parameters on the concentration of carbon monoxide, nitrogen dioxide and particulate matter was determined. The estimate of the degree of significance of the impact of weather parameters on carbon monoxide is shown in Table 3.

In the first part of Table 3, parameters of carbon monoxide emission measurement are given. Column Estimate shows values of deviation of the measured carbon monoxide in relation to a dummy variable value, which is TO EAST in this case. A deviation is determined based on three-year median values for a certain emitter. This deviation can be positive or negative. The greatest deviation was recorded for NORTH-1 emitter, where the measured value deviated by as much as 39.73 . That means that the value of NORTH-1 emitter was greater by 39.73 than the value recorded on EAST-3 emitter. The smallest deviation was recorded in the case of SOUTH-8 emitter, where the measured value deviated by -7.00 . That means that the value on JUG-8 emitter is smaller by 7.00 than the value recorded on EAST-3 emitter. Column Std. error (Standard error) is a column showing the average deviation of the measured values from the arithmetic mean of the measured values. The greatest value was recorded for WEST-2 emitter and it was 31.57. The smallest value was recorded for NORTH-1 emitter and it was 19.43. Columns 3 and 4 are significance testing between two arithmetic means. If value "t" is less than 2.58, and in the last column value "P" is greater than 0.05 , it indicates that there is a statistically significant difference between the two arithmetic means of a certain emitter and dummy variable. It is evident from 
Petrović J. et al.: Sustainable urban development and industrial pollution

the table that all emitters have a statistically significant difference between two arithmetic means.

Table 3. Weather parameters and emission of carbon monoxide

\begin{tabular}{|l|c|c|c|c|}
\hline & Estimate & Std. Error & t value & $\operatorname{Pr}(>|t|)$ \\
\hline EMITTER SOUTH-1 & 16.97 & 28.23 & 0.60 & 0.56 \\
\hline EMITTER SOUTH-5 & -13.29 & 26.15 & -0.51 & 0.62 \\
\hline EMITTER SOUTH-8 & -7.00 & 25.45 & -0.28 & 0.79 \\
\hline EMITTER NORTH-1 & 39.73 & 19.43 & 2.05 & 0.07 \\
\hline EMITER WEST-2 & -11.38 & 31.57 & -0.36 & 0.73 \\
\hline EMITTER WSET-5 & -23.71 & 24.53 & -0.97 & 0.35 \\
\hline EMITTER WEST-6D & -31.63 & 22.26 & -1.42 & 0.18 \\
\hline EMITTER WEST-6L & -7.47 & 22.75 & -0.33 & 0.75 \\
\hline TEMPERATURE & -2.99 & 3.89 & -0.77 & 0.46 \\
\hline HUMIDITY & -1.72 & 2.05 & -0.84 & 0.42 \\
\hline AIR PRESSURE & 0.96 & 0.99 & 0.97 & 0.35 \\
\hline WIND SPEED & 0.75 & 3.32 & 0.23 & 0.83 \\
\hline Residual standard error & 20.10 & & \\
\hline Multiple R-squared & 0.81 & & \\
\hline Adjusted R-squared & 0.55 & & \\
\hline p-value & $\mathbf{0 . 0 3 2}$ & & \\
\hline
\end{tabular}

Source: Authors' calculation

In the second part of Table 3, time data are given. Columns 1 and 2 indicate that there is a greater difference when temperature is concerned and at the same time the greatest error. On the other hand, the smallest difference is in the case of wind speed, and the smallest error is registered for air pressure. Columns 3 and four are significance testing between arithmetic means. If "t" value is less than 2.58 and "P" value in the last column is greater than 0.05 , it indicates that there is a statistically significant impact of the given factors on carbon monoxide emission. The most significant impact is recorded for air pressure.

The last group of data in Table 3 are finally processed data. The first result of final processing is a residual standard error, indicating aggregate deviation of the measured values of carbon monoxide from the dummy variable. In this case, the residual standard error is 20.10 , meaning that the deviation equals 20.10 .

The value of Multiple R-squared shows to what extent a deviation of carbon monoxide values is related to changes in weather parameters. In this case, the calculated value of Multiple R-squared is $81 \%$. The Adjusted R-squared is determined as a measure of preciseness of the application of panel data analysis. The closer the calculated value of the Adjusted R-squared to the value of Multiple R-squared - the more precise the statistical processing can be deemed. The Adjusted R-squared for carbon monoxide is $55 \%$. The stated 
result shows a proportionately great deviation from the Multiple R-squared, which is primarily the consequence of a small number of time series.

The p-value (statistical significance) is 0.032 . Common values are 0.05 and 0.01 . In this paper, 0.01 is used. The calculated $p$-value of 0.032 is greater than 0.01 , which means that change of weather conditions has a statistically significant impact on carbon monoxide emission, whereby the greatest individual impact is that of air pressure (0.97).

Table 4 shows the estimate of significance of the impact of weather parameters on nitrogen dioxide emission.

Table 4. Weather parameters and emission of nitrogen dioxide

\begin{tabular}{|l|c|c|c|c|}
\hline & Estimate & Std. Error & $\mathrm{t}$ value & $\operatorname{Pr}(>|\mathrm{t}|)$ \\
\hline EMITTER SOUTH-1 & 9.99 & 41.26 & 0.24 & 0.81 \\
\hline EMITTER SOUTH-5 & 0.90 & 38.21 & 0.02 & 0.98 \\
\hline EMITTER SOUTH-8 & -7.75 & 37.19 & -0.21 & 0.84 \\
\hline EMITTER NORTH-1 & 21.07 & 28.39 & 0.74 & 0.47 \\
\hline EMITTER WEST-2 & -16.82 & 46.15 & -0.36 & 0.72 \\
\hline EMITTER WEST-5 & -36.61 & 35.85 & -1.02 & 0.33 \\
\hline EMITTER WEST-6D & 82.06 & 32.53 & 2.52 & 0.03 \\
\hline EMITTER WEST-6L & 72.80 & 33.25 & 2.19 & 0.05 \\
\hline TEMPERATURE & -6.05 & 5.68 & -1.17 & 0.31 \\
\hline HUMIDITY & -3.56 & 2.99 & -0.89 & 0.26 \\
\hline AIR PRESSURE & 0.36 & 1.45 & 0.25 & 0.81 \\
\hline WIND SPEED & -7.15 & 4.85 & -1.08 & 0.17 \\
\hline Residual standard error & 29.37 & & \\
\hline Multiple R-squared & 0.80 & & \\
\hline Adjusted R-squared & 0.53 & & \\
\hline p-value & $\mathbf{0 . 0 3 9}$ &
\end{tabular}

Source: Authors' calculation

In the first part of Table 4, parameters of nitrogen dioxide emission measurement are given. Column Estimate shows values of deviation of the determined nitrogen dioxide to the dummy variable value which, in this case, is TE EAST. Deviation is determined based on median values for all three years for a specific emitter. The greatest deviation is recorded in the case of emitter WEST-6D, with the determined value deviating by as much as 82.06 . That means that the value of emitter WEST-6D is by 82.06 greater than the value recorded for emitter EAST-3. The smallest deviation is recorded for emitter SOUTH-5, where the determined value deviates by 0.90 . That means that the value for emitter SOUTH-5 is by 0.90 greater than the value recorded for emitter EAST-3. Column Std. error (Standard error) shows the average deviation of the determined values from the arithmetic mean of the determined values. The greatest value is recorded for emitter WEST-2 and it is 46.15. The smallest value is recorded for emitter NORTH-1 and it is 28.39. Columns 3 and 4 are significance testing between the two arithmetic means. If "t" value is smaller than 2.58 and the last column "P" value greater than 0.05 , 
it means that there is a statistically significant difference between the two arithmetic means of a specific emitter and dummy variable. It is clear from the table that all emitters have a statistically significant difference between the two arithmetic means.

In the second part of Table 4, weather data are given. Columns 1 and 2 indicate that the greatest difference, and at the same time a great error, is in the case of wind speed. The greatest error is recorded for temperature and there is a great deviation as well. On the other hand, air pressure records the smallest difference and the smallest error. Columns 3 and 4 are significance testing between the arithmetic means. If "t" value is less than 2.58 and the last column "P" value is greater than 0.05 , they indicate that there is a statistically significant impact of the given factors on nitrogen dioxide emission. The most significant impact is recorded for temperature.

The last group of data in Table 4 are final processing data. The first result of final processing is a residual standard error showing aggregate deviation of the measured values of nitrogen dioxide from the dummy variable. In this case, the residual standard error is 29.37 , which means that the deviation is equal to 29.37 .

The value of Multiple R-squared shows the extent to which a deviation of nitrogen dioxide value can be linked with changes of weather parameters. In this case, the measured value of Multiple R-squared is $80 \%$. The Adjusted Rsquared is determined as a measure of preciseness of application of panel data analysis. The closer the calculated value of the Adjusted R-squared to the value of Multiple R-squared - the more precise the statistical processing can be deemed. The Adjusted R-squared for nitrogen dioxide is $53 \%$. The stated result shows a proportionately great deviation from the Multiple Rsquared, which is primarily the consequence of a small number of time series.

The p-value (statistical significance) is 0.039 . Common values are 0.05 and 0.01 . In this paper, 0.01 is used. The calculated $p$-value of 0.039 is greater than 0.01 , meaning that the change of weather conditions has a statistically significant impact on nitrogen dioxide emission, whereby the greatest individual impact is that of temperature (1.17).

As the last stage in the research, an estimate of the impact of weather parameters on particulate matter was made. Results are shown in Table 5.

Table 5. Weather parameters and emission of particulate matter

\begin{tabular}{|l|c|c|c|c|}
\hline & Estimate & Std. Error & t value & $\operatorname{Pr}(>|\mathrm{t}|)$ \\
\hline EMITTER SOUTH-1 & -1.61 & 1.13 & -1.43 & 0.20 \\
\hline EMITTER SOUTH-5 & -0.79 & 0.89 & -0.89 & 0.40 \\
\hline EMITTER NORTH-1 & 2.00 & 0.68 & 2.95 & 0.02 \\
\hline EMITTER WEST-5 & -1.70 & 0.83 & -2.04 & 0.08 \\
\hline EMITTER WEST-6D & -1.49 & 0.75 & -1.99 & 0.09 \\
\hline
\end{tabular}


Petrović J. et al.: Sustainable urban development and industrial pollution

\begin{tabular}{|l|c|c|c|c|}
\hline EMITTER WEST-6L & -1.74 & 0.77 & -2.24 & 0.06 \\
\hline TEMPERATURE & -0.19 & 0.14 & -1.38 & 0.21 \\
\hline HUMIDITY & -0.10 & 0.08 & -1.37 & 0.21 \\
\hline AIR PRESSURE & 0.05 & 0.03 & 1.37 & 0.21 \\
\hline WIND SPEED & -0.16 & 0.12 & -1.39 & 0.21 \\
\hline Residual standard error & 0.65 & & \\
\hline Multiple R-squared & 0.91 & & \\
\hline Adjusted R-squared & 0.76 &
\end{tabular}

Source: Authors' calculation

In the first part of Table 5, parameters of particulate emission measurement are given. Column Estimate shows values of deviation of the measured powdery matter from the dummy variable value, which, in this case, is TE EAST. Deviation is determined based on median values for all three years for a specific emitter. The greatest deviation is recorded in the case of emitter NORTH-1, with the measured value deviating by 2.00 . That means that the value of emitter NORTH-1 is by 2.00 greater than the value recorded for emitter EAST-3. The smallest deviation is recorded for emitter SOUTH-5, where the determined value deviates by -0.79 . That means that the value for emitter SOUTH- 5 is by 0.79 smaller than the value recorded for emitter EAST3. Column Std. error (Standard error) shows the average deviation of the determined values from the arithmetic mean of the determined values. The greatest value is recorded for emitter SOUTH-1 and it is 1.13. The smallest value is recorded for emitter NORTH-1 and it is 0.68 . Columns 3 and 4 are significance testing between the two arithmetic means. If "t" value is smaller than 2.58 and the last column "P" value greater than 0.05 , it means that there is a statistically significant difference between the two arithmetic means of a specific emitter and dummy variable. It is clear from the table that all emitters have a statistically significant difference between the two arithmetic means.

In the second part of Table 5, weather data are given. Columns 1 and 2 indicate that there is the greatest difference and the biggest error is in the case of temperature. On the other hand, air pressure records the smallest difference and the smallest error. Columns 3 and 4 are significance testing between the arithmetic means. If "t" value is less than 2.58 and the last column "P" value is greater than 0.05 , they indicate that there is a statistically significant impact of the given factors on particulate matter emission. The most significant impact is recorded for air pressure.

The last group of data in Table 5 are final processing data. The first result of final processing is a residual standard error showing aggregate deviation of the measured values of particulate matter from the dummy variable. In this case, the residual standard error is 0.65 , which means that the deviation is equal to 0.65 . 
The value of Multiple R-squared shows the extent to which the deviation of particulate matter value can be linked with changes of weather parameters. In this case, the measured value of Multiple R-squared is $91 \%$. The Adjusted Rsquared is determined as a measure of preciseness of application of panel data analysis. The closer the calculated value of the Adjusted R-squared to the value of Multiple R-squared - the more precise the statistical processing can be deemed. The Adjusted R-squared for particulate matter is $76 \%$.

The $p$-value (statistical significance) is 0.014 . Common values are 0.05 and 0.01 . In this paper, 0.01 is used. The calculated $p$-value of 0.014 is greater than 0.01 , meaning that the change of weather conditions has a statistically significant impact on particulate matter emission whereby the greatest individual impact is that of air pressure (1.37.)

\subsection{Overall results}

Based on the research conducted, the obtained final results of the research on the impact of weather parameters on the concentration of pollutants from district heating plants are given in Table 6.

Table 6. Weather conditions and pollution from district heating plants

\begin{tabular}{|c|l|l|c|}
\hline Pollutant & P-value & Level of significance & $\begin{array}{c}\text { Greatest impact of weather } \\
\text { factor }\end{array}$ \\
\hline Carbon monoxide & 0.032 & Significant & Air pressure \\
\hline Nitrogen dioxide & 0.039 & Significant & Temperature \\
\hline Particulate matter & 0.014 & Significant & Air pressure \\
\hline
\end{tabular}

Source: Authors' calculation 


\section{Conclusions}

Emission of pollutants from district heating power plants is addressed in a great number of papers because those plants are located in urban areas. In addition to that, big, modern cities have their own microclimate, which depends on a great number of factors and very complex relations that exist among them. The impact of power plants on environment, i.e. the reverse impact of weather conditions on pollution and, consequentially, on the quality of life in urban areas, is of particular scientific and practical interest.

The primary goal of this paper is to define a degree of significance between weather conditions and emissions from the district heating power plants. In this specific case, the research was conducted in the city of Novi Sad, Serbia (Heating Plant Public Utility), although the result applies to other places as well. Data on carbon monoxide, nitrogen dioxide and particulate matter were analysed on 12 measurement sites. In this research, data on sulphur dioxide were not used. Data on weather conditions on the given measurement sites: air temperature, air humidity, air pressure and wind speed were used as independent variables. Data processing was performed by applying the panel data analysis method - the fixed effects model.

The main result of the research indicates that there is a statistically significant impact of weather conditions on emission of pollutants on all measurement sites. Besides, the research shows that the greatest degree of impact of weather conditions is in the case of nitrogen dioxide. Weather conditions have a minor impact on carbon monoxide emission, whereas the smallest degree of statistical significance is recorded for particulate matter.

The research shows that, observed individually, the biggest impact on carbon monoxide and powdery matter is that of air temperature. Other weather conditions do not show any statistically significant impact on pollutant emissions from district heating plants. The research also shows that the results would be more precise and better if greater time series were used, as shown in the tables by the Adjusted R-squared value for carbon monoxide, nitrogen dioxide and powdery matter parameters. In addition to that, by comparing the residual standard error, it is determined that the research is the most accurate for powdery matter.

The research shows that the panel data analysis can be used for further observations and studies of the same or similar type. Future adjustments and improvements of the data processing methodology are needed, with an aim of obtaining as precise results and data as possible to be used for the improvement of the quality of living environment and human wellbeing in general. 
Petrović J. et al.: Sustainable urban development and industrial pollution

\section{References}

Alexander, I. (2014). Developing countries experience and outlook: Getting the framework right', Utilities Policy 31: 184-187.

Al-Gharib, A.A, Elkamel, A, Baker, C.G.J. (2002). A multi-criteria decision approach for choosing and ranking $\mathrm{SO}_{2}$ emission reduction measures for a network of power stations, World Review of Science, Technology and Sustainable Development, 4: 196-225.

Arvin, M.B, Pardhan, R.P., Norman, N.R. (2015). Transportation intensity, urbanization, economic growth, and $\mathrm{CO}_{2}$ emissions in the $\mathrm{G}-20$ countries. Utilities Policy 35: 50-66.

Alanne, K., Saar, A. (2006). Distributed energy generation and sustainable development. Renewable and Sustainable Energy Reviews 10: 539-558.

Astel, A., Cozzutto, S., Cozzi., F, Adami, G., Barbieri, P., Tsakovski S., Simeonov, V. (2010). Seasonal apportionment of the sources of ambient air particulates in the city of Trieste. International Journal of Environment and Pollution 41:70-89.

Baltagi, B. H. (2013). Econometric Analysis of Panel Data, 5th Ed., John Wiley \& Sons.

Bezglaya, E.Yu, Ivleva, T.P., Smirnova, I.V. (2013). Fifty years to the air pollution observations. Russian Meteorology and Hydrology 38:645-652.

Borović, Z. S. (2014). Does Economic Freedom Impact Economic Growth: Evidence from Two Western Balkan Countries. Industry 42(2): 57-70.

Brookes, N.J., Locatelli, G. (2015). Power plants as megaprojects: Using empirics to shape policy, planning, and construction management. Utilities Policy 36: 57-66.

Carreras, G, Chellini, E., Blangiardo, M. (2012). A Bayesian model for studying urban air pollution and respiratory symptoms in children. International Journal of Environment and Health 6: 125-140.

Castelli, A.T, Anfossi, D, Ferrero, E. (2003). Evaluation of the environmental impact of two different heating scenarios in urban area. International Journal of Environment and Pollution 20: 207-217.

Chen, MY. (2013). Panel Data Analysis. Department of Finance, National Chung Hsing University.

Cheng, S., Li, J., Feng, B., Jin, Y., Hao, R. (2007). A gaussian-box modeling approach for urban air quality management in a Northern Chinese City-II. - Pollutant emission abatement. Water, Air, and Soil Pollution 178:15-36.

Cho, H.S., Choi, M. J. (2014). Effects of Compact Urban Development on Air Pollution: Empirical Evidence from Korea. Sustainability 6: 5968-5982.

Corvellec, H., Campos, M.J.Z., Zapata, P. (2013). Infrastructures, lock-in, and sustainable urban development: the case of waste incineration in the Göteborg Metropolitan Area. Journal of Cleaner Production 50:32-39.

Davies, A., Lahiri, K. (1995). A new framework for testing rationality and measuring aggregate shocks using panel data. Journal of Econometrics 68: 205-227.

Djordjevic, A et al. (2011). The effect of pollutant emission from district heating systems on the correlation between air quality and health risk. Thermal Science 15: 293-310.

Duran, J., Golušin, M., Munitlak-Ivanović, O., Jovanović, L., Andrejević, A. (2013). Renewable Energy and Socio-economic Development in the European Union. Problemy Ekorozwoju / Problems of Sustainable Development 8: 105-114. 
Ewing, R., Bartholomoew, K., Winkelman, S., Walters, J., Chen, D. (2007). Growing Cooler: The Evidence on Urban Development and Climate Change. Urban Land Institute.

Filipović, S., Miljković, M. (2014). Transition Economies During Global economic Crisis: A Difference in Differences Approach. Industry 42(3): 23-30.

Filipović, S., Miljković, M. (2011). Politika unapređenja energetske efikasnosti u industrijskom sektoru. Industry 4:225-240.

Filipović, S., Nikolić, I., Dragutinović, S. (2012). Electricity price as a factor of the natural electric power industry sustainability. Industry 4:153-171.

Finney, K.N et al. (2012). Developments to an existing city-wide district energy network - Part I: Identification of potential expansions using heat mapping. Energy Conversion and Management 62: 165-175.

Galindo, N., Varea, M., Gil-Moltó, J., Yebero, E., Nicolás, J. (2011). The Influence of Meteorology on Particulate Matter Concentrations at an Urban Mediterranean Location. Water, Air, \& Soil Pollution 215: 365-372.

$\mathrm{He}$, I., Ye, Y., Zhao, S. (2013). Numerical model-based relationship between meteorological conditions, air quality, and its implication for urban air quality management. International Journal of Environment and Pollution 53: 265-286.

Green, D. A., Turk, B.S., Gupta, R., P., Potzer, J.F., McMichael, W.J., Harrison, D.P. (2004). Capture of carbon dioxide from flue gas using solid regenerable sorbents. International Journal of Environmental Technology and Management 4: 53-67.

Gassner, K., Pushak, N. (2014). 30 years of British utility regulation: Developing country experience and outlook. Utilities Policy 31: 44-51.

Halla, F. (2007). A SWOT analysis of strategic urban development planning:The case of Dar el Salaam city in Tanzania. Habitat International 31:130-142.

Haraš-Bujanowicz, B., Janulewicz, P., Nowak, A., Krukowski, A. (2015). Evaluation of Sustainable Development in the Member States of the European Union. Problemy Ekorozwoju / Problems of Sustainable Development 10:169-177.

Heckman, J.J., Learner, E.E. (2006). Handbook of econometrics. Elsevier, Ed. 1.

Jovanović, V., Komatina, M. (2012). NOx and $\mathrm{SO}_{2}$ Emission Factors for Serbian Lignite Kolubara. Thermal Science 16: 1213-1228.

Kaasik, M., Kimmel, V., Kaasik, H. (2001). An air quality modeling system for a medium-sized town: a case study in Estonia. International Journal of Environment and Pollution 16: 519-527.

Katsoulis, B.D., Pneymatikos, J.D. (2009). Statistical analysis of urban air-pollution data in the Athens basin area, Greece. International Journal of Environment and Pollution 36:30 - 43.

Kindap, T. (2008). Identifying the Trans-Boundary Transport of Air Pollutants to the City of Istanbul Under Specific Weather Conditions. Water, Air, and Soil Pollution 189: 279-289.

Kuznetsova, I.N et al. (2008). Meteorological prerequisites of formation of severe wintertime air pollution episodes in Moscow. Russian Meteorology and Hydrology 33:167-174.

Laurikka, H., Koljonen, T. (2006). Emissions trading and investment decisions in the power sector-a case study in Finland. Energy Policy 34:1063-1074.

Leuzzi, G., Monti, P., Amicarelli, A. (2010). An urban scale model for pollutant dispersion in Rome. International Journal of Environment and Pollution 40: 85-93. 
Magiera, T., Goluchowska, B., Jabłońska, M. (2013). Technogenic Magnetic Particles in Alkaline Dusts from Power and Cement Plants. Water, Air, \& Soil Pollution 224:1389-1406.

Matyas, L., Sevestre, P. (2008). The Econometrics of Panel Data: Fundamentals and Recent Developments in Theory and Practice. Springer.

Mazzeo, N.A., Venegas, N.A. (2004). Some aspects of air pollution in Buenos Aires city. International Journal of Environment and Pollution 22: 365-78.

Meteorological yearbook, Climatology data for 2011 (2012), Republic Hydrometeorological Service Belgrade, Serbia.

Meteorological yearbook, Climatology data for 2012 (2013), Republic Hydrometeorological Service Belgrade, Serbia.

Meteorological yearbook, Climatology data for 2013 (2014), Republic Hydrometeorological Service Belgrade, Serbia.

Mikulandrić, R et al. (2012). Improvement of environmental aspects of thermal power plant operation by advanced control concepts. Thermal Science 16: 759-772.

Nikolić, I. (2015) Price determinants in newly built dwellings in Serbia, Industry, Vol. 43, No. 2, pp. $105-116$.

Piro, P., Carbone, M., Garofalo, G., Sansalone, J. (2009). Size Distribution of Wet Weather and Dry Weather Particulate Matter Entrained in Combined Flows from an Urbanizing Sewershed. Water, Air, and Soil Pollution 206: 83-94.

Poupkou, A., Symenoidis, P., Ziomas, I., Melas, D., Markakis, K. (2007). A Spatially and Temporally Disaggregated Anthropogenic Emission Inventory in the Southern Balkan Region. Water, Air, and Soil Pollution 185: 335-348.

Poykio, R., Nurmesniemi, H., Keiski, R.L. (2008). Evaluating the concentrations of partitioned heavy metals in fly ash from a medium-sized (32 MW) municipal district heating plant with respect to the new Finnish limit values. International Journal of Environment and Waste Management 2: 610-624.

Report on the measurement of emissions of pollutants in the air (2011), Novi Sad, Serbia.

Report on the measurement of emissions of pollutants in the air (2012), Novi Sad, Serbia.

Report on the measurement of emissions of pollutants in the air (2013), Novi Sad, Serbia.

Ricardo, L.B., Almeida, A.F., Filho, V.N., Aguiar, M.L., Goncalves, J.A.S., Coury, J.R. (2004). Atmospheric particulate matter in the city of Sao Carlos/SP, Brazil. International Journal of Environment and Pollution 22: 476 - 489.

Rocher, V., Azimi, S., Gasperi, J., Beuvin, L., Muller, M., Moilleron, R., Chebbo, G. (2004). Hydrocarbons and Metals in Atmospheric Deposition and Roof Runoff in Central Paris. Water, Air, and Soil Pollution 159: 67-86.

Ryaboshapko, A.G., Revokatova, A.P. (2015). A potential role of the negative emission of carbon dioxide in solving the climate problem. Russian Meteorology and Hydrology 40: 443-455.

Shahgedanova, M., Burt, T.P., Davies, T.D. (1999). Carbon Monoxide and Nitrogen Oxides Pollution in Moscow. Water, Air, and Soil Pollution 122: 107-131.

Sirotenko, O.D., Gruza, G.V., Rankova, E.Yu., Abashina, E.V., Pavlova, V.N. (2007). Modern climate-related changes in heat supply, moistening, and productivity of the agro-sphere in Russia. Russian Meteorology and Hydrology 32: 538546 
Staffogia, M et al. (2008). Does Temperature Modify the Association between Air Pollution and Mortality? A Multi-city Case-Crossover Analysis in Italy. American Journal of Epidemiology 167: 1476-1485.

Stefanović, G et al. (2008). Pollution data tracking in the Western-Balkan countries: a state-of-the-art review. Thermal Science 12: 105-112.

Stojiljković, $M$ et al. (2010). Effects of implementation of cogeneration in the district heating system of the Faculty of Mechanical Engineering in Niš. Thermal Science 14: 41-51.

Streets, D.G., Waldhoff, S.T. (2000). Present and future emissions of air pollutants in China: $\mathrm{SO}_{2}$, NOx, and CO. Atmospheric Environment 34: 363-374.

Sucic, B., Pusnik, M., Casen, M., Merse, S. (2014). Quality of Living and Sustainability Indicators - City of Ljubljana, Vision 2050. Industry 42(1): 109-135.

Tang, L. Rayner, D., Haeger-Eugensson, M. (2011). Have Meteorological Conditions Reduced $\mathrm{NO}_{2}$ Concentrations from Local Emission Sources in Gothenburg? Water, Air, \& Soil Pollution 221: 275-286.

Tomasović, N. (2014). Prospective thermal power generation in the Western Balkan Countries. Thermal Science 19: 357-370.

Tsai, Y., Lin, Yi.H., Lee, S.Z. (2003). Visibility Variation with Air Qualities in the Metropolitan Area in Southern Taiwan. Water, Air, and Soil Pollution 144: 19-40.

Urumqi District Heating Project: Environment impact assessment report for Shayibake district heating network component (2011). Report, World Bank.

Valkonen, E., Harkonen, A., F., Kukkonen, J., Rantakrans, E., Jalkanen, L., Haarala, S. (1995). Application of dispersion models for evaluating the influence of urban air pollution on human health. International Journal of Environment and Pollution 5: 557-566.

Wissner, M. (2014). Regulation of district-heating systems. Utilities Policy 31: 63-73.

Wooldridge, J.M. (2002). Econometric Analysis of Cross Section and Panel Data, The MIT Press, Cambridge.

Xian, G., Crane, M., Su, J. (2007). An analysis of urban development and its environmental impact on the Tampa Bay watershed. Journal of Environmental Management 85:965-976.

Yigitcanar, T., O`Connor, K., Westerman, C. (2008). The making of knowledge cities: Melbourne's knowledge -based urban development experience. Cities 25:63-72.

Yucheng, C., Ce, W. (2015). Sustainable Mitigation of Methane Emission by Natural Processes. Problemy Ekorozwoju/Problems of Sustainable Development 1: 117121.

Zanobetti, A., Peters, A. (2015). Disentangling interactions between atmospheric pollution and weather. Journal of Epidemiology and Community Health 69: 613615.

Zhang, L., Chen, C., Murlis, J. (2001). Study on Winter Air Pollution Control in Lanzhou, China. Water, Air and Soil Pollution 127: 351-372.

Zuo C.G., Chen, Q. (2015). Challenges to Sustainability of Resource-exhausted Cities: A Case Study of Lengshuijiang, China. Problemy Ekorozwoju/Problems of Sustainable Development 10: 89-98.

Želazna, A., Golebiowska, J. (2015). The Measures of Sustainable Development - a Study Based on the European Monitoring of Energy-related Indicators. Problemy Ekorozwoju / Problems of Sustainable Development 10: 169-177. 